vailable online at website : http://e-journal.adpgmiindonesia.com/index.php/jmie

JMIE: Journal of Madrasah Ibtidaiyah Education, 2(1), 2018, 97-118

\title{
PENGARUH PEMBELAJARAN PENDIDIKAN IPS MI/SD TERHADAP PEMBENTUKAN KARAKTER PEDULI SOSIAL MAHASISWA PGMI UNISKA MAB BANJARMASIN
}

\author{
Barsihanor, H. Abdul Hafiz \\ Prodi PGMI Fakultas Studi Islam \\ Universitas Islam Kalimantan Muhammad Arsyad Al-Banjari Banjarmasin \\ e-mail: barsihanor90@gmail.com, abdulhafiz haji@gmail.com
}

Naskah diterima : 25 Februari 2018, direvisi : 28 Maret 2018, disetujui : 21 April 2018

\begin{abstract}
This research aims to know the influence of learning Education sosial studies elementary school against the formation of character social care students elementary school Islamic University of Kalimantan Muhammad Arsyad Al-Banjari Banjarmasin. This research using quantitative research approach with this type of correlation is Expost Facto. As for the data source or the respondents in this study are students elementary school Islamic University of Kalimantan Muhammad Arsyad Al-Banjari Banjarmasin four semester. As for the data collection Techniques used are observation, documentation, and question form. Before doing research, the instrument of research first tested the validity and reliability. The next test of its homogeneity and normality. After the data collected recently done data analysis. Analysis of the data used is the formula of the percentage and simple linear regression. From the results of the research there are the influence that is experienced by sosial studies education learning toward the formation of social caring character of students is $67 \%$, and $33 \%$ there are other factors that influence.
\end{abstract}

Keywords: Educational sosial studies elementary school, Character, Social Care

Pengutipan: Abdul Razak, Rumainur. (2018). Pengarub Pembelajaran Pendidikan IPS MI/SD terhadap Pembentukan Karakter Peduli Sosial Mahasiswa PGMI UNISKA MAB Banjarmasin. JMIE: Journal of Madrasah Ibtidaiyah Education, 2(1), 2018, 97-118. jmie.v2i1.56. 


\section{PENDAHULUAN}

Pendidikan merupakan tempat bagi setiap orang untuk meningkatkan kemampuan dan pengetahuaanya, melalui pendidikan para peserta didik akan dibekali ilmu dan keahlian, yang nantinya dapat berguna bagi kehidupannya. Pendidikan juga merupakan sarana bagi setiap orang yang ingin mengembangkan potensi yang ada pada dirinya. Disamping sebagai media peningkatan kualitas manusia, pendidikan juga harus mampu menciptakan manusia-manusia yang memiliki karakter yang baik. Oleh kerena itu tuga lembaga pendidikan tidak hanya mencetak manusia yang cerdas secara kognitif, akan tetapi juga mencetak para manusia yang berkarakter. Selain faktor pendidikan karakter juga dapat dipengaruhi oleh faktor keturunan atau lingkungan. Karakter individu akan sangat mempengaruhi dalam kehidupannya sehari-hari. Tugas lembaga pendidikan dalam pembentukan karakter tidak hanya dibebankan pada jenjang SD, SMP, atau SMA saja, akan tetapi juga pada jenjang perguruan tinggi. Mahasiswa tidak hanya belajar pengetahuan dan keterampilan semata, akan tetapi juga dibekali dengan pendidikan karakter, salah satunya adalah karakter peduli sosial.

Mahasiswa merupakan juga bagian dari masyarakat yang terdidik, yang tugasnya tidak hanya sekedar belajar, tetapi juga sebagai agent of change dalam pembangunan masyarakat, oleh sebab itu mahasiswa sudah wajarnya peduli dengan kejadian atau masalah sosial yang terjadi di lingkungan masyarakat. Rasa kepedulian ini tentu, tidak tumbuh dengan sendirinya, mahasiswa harus lebih banyak bersosialisasi di lingkungan masyarakat, sehingga mereka akan mengetahui permasalahan yang terjadi di masyarakat dan kehadirannya diharapkan mampu memberikan kontribusi terhadap pembangunan masyarakat.

Kepedulian sosial di masyarakat lebih sering diartikan sebagai perbuatan baik individu kepada orang lain di sekitarnya. Darmiyati Zuchdi mengungkapkan peduli sosial merupakan perilaku yang selalu ingin membantu orang lain yang memerlukan. (Zuchdi, 2007). Sedangkan Elly M. Setiadi, dkk menjelaskan lingkungan sosial lebih merujuk pada lingkungan tempat interaksi sosial terjadi, baik dengan anggota keluarga, teman, dan kelompok sosial lain yang lebih besar. (Elly \& dkk, 2012). Furqon dalam (Hidayatullah, 2010) menjelaskan ada beberapa indikator yang dapat digunakan untuk mendeskripsikan karakter peduli sosial, antara lain: 1) Peduli pada orang lain. 2) Menghargai orang lain. 3) Menghormati hak-hak orang lain. 4) Bekerjasama. 5) Membantu dan menolong orang lain. Dengan demikian indikator karakter peduli sosial adalah sikap peduli kepada sesama, bersosialisasi di masyarakat, bersikap santun dan mau bekerjasama dengan anggota masyarakat.

Perilaku peduli sosial hendaknya dimiliki oleh semua anggota masyarakat, kerena hal tersebut berpengaruh pada kehidupan masyarakat, dan menjaga keselarasan hubungan di masyarakat. Setiap individu pasti memiliki karakteristik yang berbeda- 
beda dan saling melengkapi satu sama lain, pemahaman individu sangat penting dipahami oleh setiap individu, dengan begitu stabilitas hubungan di masyarakat akan tetap terjaga dengan baik, khususnya pada era dimana semakin berkurangnya nilai kemanusiaan pada bangsa kita.

Warsono mengungkapkan bahwa "nilai kemanusiaan, seakan semakin sulit ditemukan. Banyak orang yang tidak lagi peduli terhadap penderitaan orang lain, bahkan cenderung mengeksploitasi orang lain. Hati kita sudah tidak tersentuh lagi melihat kemiskinan dan penderitaan orang-orang di sekitar kita, yang jumlahnya semakin banyak". (Warsono, 2006). Hal ini juga sebagaimana yang diungkapkan oleh Somad, diantaranya: (1) Generasi muda kita lebih mudah terpropokasi oleh isu-isu yang belum jelas adanya; (2) Meningkatnya kriminalitas di kalangan anak muda, seperti pencurian, perampokan, pemerkosaan, perkelahian dan pencurian. (3) Sikap dan perilaku anak muda kita sekarang cendrung mengancam keutuhan kesatuan negara kita, hal tersebut tidak lepas dari perkembangan iptek yang semakin canggih. (4) Zaman sekarang setiap orang dituntut untuk bisa bersaing demi bisa menjalani kehidupan yang layak. (5) Dekradasi moral, pada aspek pergaulan pada kalangan muda semakin meningkat. (Somad, 2006, p. 1).

Pendidikan kita terlihat masih belum mampu membendung arus negatif globalisasi, Pelaksanaan pendidikan karakter dirasa masih belum mampu melahirkan generasi yang cerdas dan berkarakter. Masih banyak perilaku-perilaku mahasiswa dan lulusan yang menyimpang dari nilai, agama norma dan peraturan yang ada, misalnya mahasiswa terlibat narkoba, perkelahian, tawuran, dan aksi bullying. Perilaku bullying padaa akhir-akhir ini kerap terjadi di dunia pendidikan, termasuk pada tingkat perguruan tinggi, tidak jarang anak yang memiliki kekurangan menjadi bahan bullying oleh anak yang normal lainnya, kerena mereka merasa lebih hebat dari individu yang mengalami kekurangan. Akhir-akhir ini viral di media sosial beberapa mahasiswa sedang membullying mahasiswa di fabel. Permasalahan ini muncul salah satunya disebabkan kurangnya karakter peduli terhadap sesama, terlebih kepada orang lain yang memerlukan bantuan.

Pada observasi sebelum penelitian penulis melihat mahasiswa lebih menunjukkan sikap individualistisnya, dan kurang terlihat jiwa kepeduliannya kepada mahasiswa yang lain, terlebih yang tidak masuk dalam kelompok nya. Mahasiswa cendrung untuk bersosialisasi dengan kelompoknya asaja atau geng nya saja. Disamping permasalahan tersebut di atas, kurangnya jiwa peduli sosial mahasiswa juga di tunjukkan ketika peneliti tanyakan kepada mahasiswa, apa yang mereka lakukan jika melihat orang yang sedang kehabisan bensin atau kemirisan ban di pinggir jalan, hampir sebagian besar dari mereka menjawab di biarkan saja, dengan alasan tidak mengenal orang yang lagi kesusahan tersebut. Hal ini menunjukkan belum terbentuknya perilaku peduli sosial 
pada jiwa para mahasiswa. Berdasarkan pada kondisi tersebut, peneliti tertarik untuk melakukan penelitian tentang "Pengaruh Pembelajaran Pendidikan IPS MI/SD terhadap Pembentukan Karakter Peduli Sosial Mahasiswa PGMI UNISKA MAB Banjarmasin".

\section{KARAKTER PEDUL SOSIAL}

Karakter merupakan perilaku yang dilakukan tanpa spontan, tanpa pemikiran terlebih dahulu atau di pengaruhi oleh faktor yang lain. Dalam KBBI karakter diartikan sebagai sifat-sifat kejiwaan, akhlak atau budi pekerti yang membedakan seseorang dengan orang lain. Sedangkan menurut Rutland dalam M. Furqon Hidayatullah menjelaskan bahwa "karakter berasal dari akar kata bahasa Latin yang berarti "dipahat". Secara harfiah, karakter artinya adalah kualitas mental atau moral, kekuatan moral, nama atau reputasinya". (Asmani, 2011). Sikap peduli memiliki arti tersendiri, yakni sikaf atau tindakan yang senantiasa tergugah hatinya untuk membantu orang lain dan masyarakat yang sedang membutuhkan. (Narwati, 2011)

Peduli sosial menginginkan adanya kepekaan hati terhadap situasi dan keadaan masyarakat sekitar. Pilar kepedulian dirumuskan didalam beberapa lembaga diantaranya Indonesia Heritage Foundation merumuskan Sembilan karakter dasar yang menjadi tujuan pendidikan karakter, yaitu:

1. Cinta Tuhan dan alam semesta beserta isinya.

2. Tanggung jawab, kedisiplinan, dan kemandirian.

3. Kejujuran

4. Hormat dan santun

5. Kasih sayang, kepedulian, dan kerjasama.

6. Percaya diri, kreatif, kerja keras dan pantang menyerah.

7. Keadilan dan kepemimpinan.

8. Baik dan rendah hati.

9. Toleransi, cinta damai dan persatuan. (Narwati, 2011)

Kepedulian sosial sebagai salah satu inti dalam implementasi pendidikan karakter adalah adanya tindakan yang senantiasa ingin membantu orang lain yang sedang memerlukan bantuan. (Listyarti, 2012) Kepedulian sosial ini merupakan implementasi kesadaran manusia sebagai makhluk sosial yang tidak dapat hidup sendiri. Manusia membutuhkan orang lain untuk memenuhi kebutuhannya sehingga ada sifat saling tergantung antara satu individu dengan individu lain. (Yaumi, 2004) Sebagai makhluk sosial tentunya manusia akan ikut merasakan penderitaan dan kesulitan orang lain sehingga ada keinginan untuk memberikan pertolongan dan bantuan kepada orangorang yang kesulitan. Manusia mempunyai rasa empati, rasa merasakan apa yang 
dirasakan orang lain dan dengan itu tergeraklah hatinya untuk menolong orang lain. (Mustari, 2014) Oleh karena itu pada hakikatnya manusia adalah makhluk yang suka tolong-menolong.

Nilai inti kepedulian sosial dalam pendidikan karakter di Indonesia dapat diturunkan menjadi nilai-nilai turunan yaitu: kasih sayang, perhatian, kebijakan, adab, komitmen, keharuan, kegotong royongan, santun, rasa hormat, demokratis, kebijaksanaan, disiplin, empati, kesetaraan, suka pemaaf, persahabatan, kesahajaan, kedermawanan, kelemah lembutan, pandai berterima kasih, pandai bersyukur, suka membantu, suka menghormati, keramah tamahan, kemanusiaan, kerendah hatian, kesetiaan, moderasi, kelembutan hati, kepatuhan, kebersamaan, toleransi dan punya rasa humor. (Samani \& Hariyanto, 2014). Nilai-nilai turunan tersebut dapat dijadikan indikator mengenai karakter kepedulian sosial. Individu yang memiliki kepedulian sosial akan mampu berhadapan dengan lingkungannya dan menampakkan sifat-sifat positif seperti yang dirinci di atas.

Seseorang akan menolong orang lain atau melakukan kepedulian sosial dengan alasan berikut: (Mustari, 2014)

1. Teori ongkos hasil

Ini teori berpandangan bahwa orang merasa tidak nyman ketika ia mengetahui orang lain yang membutuhkan pertolongan dan akan muncul keinginan untuk membantu meringankan kesulitan orang tersebut, tanpa memikirkan upah atau balasan dari orang yang mereka tolong. Orang yang tidak mempunyai niat untuk menolong orang lain disebabkan tidak adanya kepekaan sosial yang terjadi dilingkungan masyarakat, serta tidak merasa bertanggung jawab terhadap keadaan yang terjadi di lingkungan masyarakat.

2. Teori empati-altruisme

Menurut teori ini jiwa penolong akan muncul disebabkan adanya perasaan ikut merasakan apa yang sedang dialami oleh orang lain, hal ini pula yang menimbulkan perasaan kalau tolong menolong, sama dengan menolong diri sendiri, atau yang disebut dengan kebaikan altruis, disamping itu empati juga bagian terpenting dalam pemberian bantuan.(Budiningsih, 2004)

3. Teori evolusi-sosialis

Teori ini berpandangan bahwa menolong orang lain pada dasarnya mendukung daya taha hidup rasa dan kelompoknya. Dia akan selalu memprioritaskan kepentingan kelompoknya dari pada kepentingan diri nya sendiri, bahkan terkadang dia mengorbankan dirinya untuk keselamatan orang lain.

Pendidikan peduli sosial atau suka menolong dipengaruhi oleh faktor-faktor peningkat yaitu: (Mustari, 2014) 
1. Mengurangi ambiguitas, meningkatkan rasa tanggung jawab.

Ajakan secara langsung untuk membantu orang lain jauh lebih efektif dari pada melalui poster atau pengumuman media. Himbauan non verbal dapat efektif jika di personalisasikan, Pengurangan anonimitas juga bisa membantu peningkatan rasa tolong menolong

2. Rasa bersalah dan perhatian untuk citra diri.

Orang yang kedapatan melakukan pelanggaran memungkin mereka untuk memberi pertolongan dari pada mereka yang tidak tertangkap basah. Orang yang membuka pintu sambil tersenyum, lebih besar kemungkinan untuk membantu orang lain yang datang dengan meminta pertolongan. Pemberian label suka menolong juga mampu meningkatkan peran pertolongan.

3. Pengajaran keterlibatan moral.

Mengundang orang yang kaya dan memberikan pemahaman kepada mereka untuk memikirkan nasib orang lain dan membayangkan apa yang merka rasakan dapat membantu meningkatkan jiwa tolong menolong.

4. Mencontohkan altruisme.

Kita jangan memberikan berita yang yang negatif-negatif, akan tetapi maslah sebaliknya memberitakan hal-hal yang positif seperti maraknya kerjasama sosial, kejujuran, dan hidup sederhana.

\section{NILAI-NILAI KEPEDULIAN SOSIAL DALAM ISLAM}

Dalam Islam istilah saling tolong menolong dikenal dengan "taawun". Islam sangat menganjurkan kepada umatnya untuk saling tolong menolong dalam hal kebaikan dan ketakwaan serta menganjurkan kita untuk tidak melakukan tolong menolong dalam kejahatan dan permusuhan.

Orang-orang yang sangat dianjurkan oleh islam untuk diberikan pertolongan adalah fakir miskin, anak yatim dan orang-orang yang tertimpa musibah. Disamping itu Islam mewajibkan bagi umatnya yang memiliki kelebihan harta untuk mengeluarkan sebagian hartanya kepada orang lain, dalam bentuk zakat, infak, shodaqoh serta kegiatan sosial lain yang bermanfaat bagi masyarakat. Islam selalu peduli kepada seluruh umat termasuk mereka yang membutuhkan.

Nilai nilai peduli sosial dalam Islam juga banyak di sebutkan di dalam Al-qur'an seperti dalam Surah Al-Maun ayat 1-3, ayat tersebut menjelaskan bahwa pendusta agama adalah orang-orang yang menghardik anak yatim dan tidak mau memberi makan orang-orang miskin. Ayat tersebut memberikan pengertian pada kita bahwa Islam sangat menganjurkan kepedulian sosial, bahkan ketika seorang muslim tidak 
peduli dengan lingkungan sosialnya dan tidak peduli dengan keadaan orang-orang miskin di sekitarnya maka ia disebut pendusta agama. Ibadah kepada Allah bukan hanya hubungan vertikal berupa ritual sholat dan ibadah lain. Kegiatan sosial kemasyarakatan juga menjadi bentuk ketaatan manusia kepada Allah.

Dengan peduli kepada orang-orang yang membutuhkan, menyantuni anak-anak yatim, bersedekah kepada fakir miskin maka seorang muslim telah melakukan kebaikan sebagai wujud ketaatan kepada Allah SWT. Hal tersebut termasuk bentuk ibadah yaitu beribadah dengan keshalihan sosial sebab berbuat baik kepada sesame adalah bentuk kebaikan, sedang segala bentuk kebaikan bernilai ibadah.

\section{PEMBELAJARAN IPS MI}

Ilmu Pengetahuan Sosial atau disingkat IPS adalah pelajaran yang mencoba untuk menelaah dan mengananilis masalah-masalah yang terjadi dalam masyarakat yang muncul seiring dengan moderinsasi dan globalisasi yang terjadi, yang ditandai oleh perkembangan ilmu pengetahuan, teknologi dan komunikasi. Disamping itu IPS juga menjadikan masalah-masalah sosial budaya yang terdapat di masyarakat dan lingkungannya maupun yang ada di negara lain pada masa lampau, masa sekarang serta mengantisipasi perubahan sosial budaya beserta pengaruhnya terhadap kelangsungan hidup manusia di masa yang akan datang sebagai bahan kajiannya. Secara spesifik IPS membahas hubungan manusia dalam konteks sosialnya dengan masyarakat dan tingkah laku masyarakat.

Penerapan pelajaran IPS di Indonesia di ilhami dari pengajaran social studies di Amerika Serikat. Penerapan social studies di Amerika Serikat dilatarbelakangi oleh perpecahan di antara ras yang ada disana. Amerika Serikat terdiri dari berbagai macam ras diantaranya ras Indian yang merupakan penduduk asli, ras kulit putih yang datang dari Eropa dan ras Negro yang didatangkan dari Afrika untuk dipekerjakan di perkebunan-perkebunan negara tersebut. Pada mulanya memang tidak terjadi permasalahan, namun setelah terjadinya perang budak antara utara dan selatan, mulai adanya kesulitan, kerena penduduk yang berbeda ras tersebut merasa sulit hidup menjadi satu bangsa. Disamping permasalahan itu, terjadinya perbedaan sosial ekonomi yang sangat tajam juga merupakan latar belakang masuknya social studies ke dalam kurikulum sekolah di negara bagian Wisconsin pada tahun 1892. Setelah dilakukan penelitian, maka pada awal abad 20, sebuah Komisi Nasional dari The National Education Association memberikan rekomendasi tentang perlunya social studies dimasukkan ke dalam kurikulum semua sekolah dasar dan sekolah menengah Amerika Serikat. Adapun wujud social studies ketika lahir merupakan semacam ramuan dari mata pelajaran sejarah, geografi dan civics. 
Latar belakang masuknya pelajaran IPS dalam kurikulum sekolah di Indonesia juga hampir sama dengan terjadi di negara-negara lain, di antaranya disebabkan kekacauan situasi dan pertentangan politik kondisi keragaman budaya bangsa (multikultur) yang sangat rentan terjadinya konflik. Sehingga, sebagai akibat konflik dan situasi nasional bangsa yang tidak stabil, terlebih adanya pemberontakan G30S/PKI dan berbagai masalah nasional lainnya di pandang perlu memasukan program pendidikan sebagai propaganda dan penanaman nilai-nilai sosial budaya masyarakat, berbangsa dan bernegara ke dalam kurikulum sekolah.

Mata pelajaran IPS secara resmi di muat pada kurikulum pada tahun 1974, dan satu tahun setelah itu mata pelajaran IPS sudah tercantum pada kurikulum SD, SMP, dan SMU, oleh kerena itu Ilmu Pengetahuan Sosial (IPS) di Indonesia kelahirannya bersamaan dengan lahirnya kurikulum tahun 1975. Sedangkan implementasinya secara bertahap yang dimulai pada tahun 1976. Sampai sekarang mata Pelajaran IPS ada dalam kurikulum sekolah, namun ada beberapa perubahan, seperti pada kurikulum 2013, mata pelajaran IPS kelas rendah terintegrasikan kontennya dengan mata pelajaran lain. Pengintegrasiannya dilakukan ke dalam mata pelajaran PPKn, Bahasa Indonesia, dan Matematika. Integrasi tersebut didasarkan pada keterdekatan makna dari konten Kompetensi Dasar IPS dengan konten Pendidikan Agama dan Budi Pekerti, PPKn, Bahasa Indonesia, Matematika, serta Pendidikan Jasmani, Olahraga dan Kesehatan yang berlaku untuk kelas I, II, dan III. Sementara itu, untuk kelas IV, V dan VI, Kompetensi Dasar IPS berdiri sendiri dan kemudian diintegrasikan ke dalam tema-tema yang ada untuk kelas IV, V dan VI.

Di era globalisasi ini dunia dituntut untuk membekali peserta didiknya dengan berbagai kompetensi dan keahlian khusus, tak terkecuali keterampilan sosial, untuk itu IPS diperlukan sebagai pengetahuan yang mampu mengharmoniskan laju perkembangan IPTEK dan pengajaran di sekolah. Sebab IPS mampu melakukan lompatan-lompatan ilmu secara konsepsional untuk kepentingan praktis kehidupan baru yang sesuai dengan keadaan dan zaman. Maka melihat jenis dan susunan konsep/topik dalam IPS sungguh sangat banyak bervariasi dari berbagai ilmu sosial serta dari tuntutan-tuntutan persoalan kehidupan praktis.

IPS merupakan integrasi berbagai cabang ilmu-ilmu sosial, seperti sosiologi, sejarah, geografi, ekonomi, politik, hukum, dan budaya. Pembelajaran yang dilaksanakan pada jenjang sekolah dasar yaitu dari kelas rendah sampai kelas tinggi. Untuk kelas rendah pembelajaran IPS SD dilaksanakan melalui pembelajaran terpadu yang disebut dengan tematik. Untuk di kelas tinggi IPS sebagai suatu pembelajaran mandiri yang mengkaji berbagai aspek ilmu sosial, yaitu sosiologi, sejarah, geografi, ekonomi, politik, hukum, dan budaya. Pembelajarannya lebih menekankan pada kemampuan intelektual/kognitif anak pada tingkatan kongkrit operasional. 
Beberapa model penerapan pendekatan tematik/terpadu internal dalam pembelajaran IPS dapat dikategorikan sebagai berikut.

1. Model Integrasi Berdasarkan Topik

Dalam pembelajaran IPS keterpaduan dapat dilakukan berdasarkan topik yang terkait, misalnya 'Kegiatan ekonomi penduduk'. Kegiatan ekonomi penduduk dalam yang dikembangkan dan ditinjau dari berbagai disiplin ilmu yang tercakup dalam IPS. Kegiatan ekonomi penduduk dalam hal ini ditinjau dari persebaran dan kondisi fisis-geografis yang tercakup dalam disiplin Geografi. Secara sosiologis,

2. Model Integrasi Berdasarkan Potensi Utama

Keterpaduan IPS dapat dikembangkan melalui topik yang didasarkan pada potensi utama yang ada di wilayah setempat; sebagai contoh, "Potensi Bali Sebagai Daerah Tujuan Wisata". Dalam pembelajaran yang dikembangkan dalam Kebudayaan Bali dikaji dan ditinjau dari faktor alam, historis kronologis dan kausalitas, serta perilaku masyarakat terhadap aturan. Melalui kajian potensi utama yang terdapat di daerahnya, maka peserta didik selain dapat memahami kondisi daerahnya juga sekaligus memahami Kompetensi Dasar yang terdapat pada beberapa disiplin yang tergabung dalam IPS.

\section{Model Integrasi Berdasarkan Permasalahan}

Model pembelajaran terpadu pada IPS yang lainnya adalah berdasarkan permasalahan yang ada, contohnya adalah "Tenaga Kerja Indonesia". Pada pembelajaran terpadu, Tenaga Kerja Indonesia ditinjau dari beberapa faktor sosial yang mempengaruhinya. Di antaranya adalah faktor geografi, ekonomi, sosiologi, dan historis. (Saputra, 2009).

Menurut Ischak, dalam (Sari, 2014) tujuan pendidikan IPS di SD adalah sebagai berikut: 1) Membekali anak didik dengan pengetahuan sosial yang berguna dalam kehidupan kelak di masyarakat. 2) Membekali anak didik dengan kemampuan mengidentifikasi, menganalisis dan menyusun alternatif pemecahan masalah sosial yang terjadi dalam kehidupan masyarakat. 3) Membekali anak didik dengan kemampuan berkomunikasi dengan sesama warga masyarakat dan berbagai bidang keilmuan serta bidang keahlian. 4) Membekali anak didik dengan kesadaran, sikap mental yang positif dan keterampilan terhadap pemanfaatan lingkungan hidup yang menjadi bagian dari kehidupan tersebut. 5) Membekali anak didik dengan kemampuan mengembangkan pengetahuan dan keilmuan IPS sesuai dengan perkembangan kehidupan masyarakat, ilmu pengetahuan dan teknologi. 
Menurut Nurhadi dalam (Apriyanti, 2014) IPS memiliki beberapa karakteristik sebagai berikut:

1. IPS merupakan gabungan dari unsur - unsur geografi, sejarah, ekonomi, hukum, politik, kewarganegaraan, sosiologi, bahkan juga bidang humaniora, pendidikan, dan agama,

2. Standar kompetensi dan kompetensi dasar berasal dari struktur keilmuan geografi, sejarah, ekonomi, dan sosiologi, yang dikemas sedemikian rupa sehingga menjadi pokok bahasan atau topik (tema) tertentu,

3. Standar kompetensi dan kompetensi dasar juga menyangkut berbagai masalah sosial yang dirumuskan dengan pendekatan interdisipliner dan multidisipliner,

4. Standar kompetensi dan kompetensi dasar dapat menyangkut peristiwa dan perubahan kehidupan masyarakat dengan prinsip sebab akibat, kewilayahan, adaptasi dan pengelolaan lingkungan, struktur, proses dan masalah sosial, serta upaya - upaya perjuangan hidup agar survive seperti pemenuhan kebutuhan, kekuasaan, keadilan, dan jaminan keamanan,

5. Standar kompetensi dan kompetensi dasar IPS menggunakan tiga dimensi dalam mengkaji dan memahami fenomena sosial serta kehidupan manusia secara keseluruhan.

\section{METODE PENELTTAN}

Penelitian ini adalah korelasi yang bersifat Expost Facto adalah suatu penelitian yang dilakukan untuk meneliti peristiwa yang telah terjadi dan kemudian menurun ke belakang. Melalui data tersebut untuk menemukan faktor-faktor yang meendahului dan menemukan sebab-sebab yang mungkin atas peristiwa yang diteliti. (Sugiono, 2005).

Sedangakan jenis penelitian adalah penelitian korelasi, yaitu penelitian yang dimaksudkan untuk mengetahui ada atau tidaknya korelasi antara dua variabel atau lebih. (Arikunto, 2006).

Adapun paradigma penelitiannya adalah untuk mencari atau mengetahui pengaruh pembelajaran pendidikan IPS MI/SD terhadap karakter peduli social mahasiswa PGMI UNISKA MAB Banjarmasin. Pembelajaran pendidikan IPS MI/SD sebagai variabel independent (variabel bebas). Karakter peduli social sebagai variabel dependent (variabel terikat). Dan bentuk hubungan ini dapat digambarkan dengan paradigma sebagai berikut: 


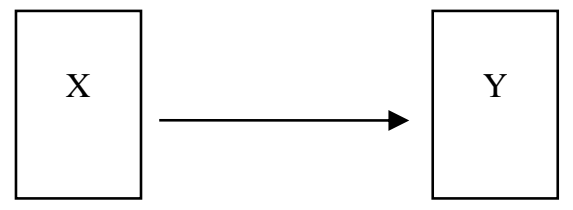

Keterangan :

$\begin{array}{lll}\mathrm{X} & \text { : Pembelajaran Pendidikan IPS MI/SD } & \text { (variabel bebas ) } \\ \mathrm{Y} & : \text { Karakter Peduli Sosial } & \text { (variabel terikat) }\end{array}$

Penelitian ini akan dilakukan di Universitas Islam Kalimantan Fakultas Studi Islam Program Studi Pendidikan Guru Madrasah Ibtidaiyah, Jl. Adhyaksa, No. 2 Kayu Tangi. Dalam penelitian populasi merupakan komponen yang mutlak diperlukan. Populasi adalah wilayah generalisasi yang terdiri atas obyek atau subyek yang mempunyai kualitas dan karakteristik tertentu yang ditetapkan oleh peneliti untuk dipelajari dan kemudian ditarik kesimpulannya. Populasi bukan hanya orang, tetapi juga obyek dan tanda-tanda alam yang lain. Populasi juga bukan sekedar jumlah yang ada pada obyek atau subyek yang dipelajari, tetapi meliputi seluruh karakteristik atau sifat yang dimiliki oleh subyek atau obyek itu. (Sugiono, 2005) Populasi dalam penelitian ini adalah mahasiswa PGMI UNISKA MAB Banjarmasin semester IV. Adapun jumlah populasi pada PGMI UNISKA MAB Banjarmasin semester IV adalah berjumlah 51. Peneliti ini menggunakan seluruh populasi sebagai sampel dikarenakan jumlah sampel kurang dari 100, sehingga penelitian ini disebut penelitian populasi.

Dalam penelitian ini penulis menggunakan penelitian kuantitatif, oleh karena itu data yang diperoleh nantinya berupa angka. Dari angka yang diperoleh akan dianalisis lebih lanjut dalam analisis data. Adapun sumber data atau responden dalam penelitian ini adalah mahasiswa PGMI Semester IV Universitas Islam Kalimantan yang berjumlah 51. Tehnik pengumpulan data merupakan langkah yang paling utama dalam penelitian, karena tujuan utama mendapatkan data. Pengumpulan data dapat di lakukan dalam berbagai setting, berbagai sumber, dan berbagai cara. Dalam rangka pengukuran dan pengkajian hipotesis maka perlu dilakukan pengumpulan data peneliti dalam tehnik pengumpulan data menggunakan angket. Angket atau kuesioner merupakan tehnik pengumpulan data yang di lakukan dengan cara memberi seperangkat pertanyaan yang tertulis dengan responden untuk di jawab (Sugiono, 2005).

Teknik angket ini digunakan untuk mengumpulkan data mengenai pembelajaran pendidikan IPS MI/SD dan karakter peduli social mahasiswa PGMI UNISKA MAB Banjarmasin, adapun jenis angket yang digunakan dalam penelitian ini adalah angket tertutup yang bersifat langsung dengan bentuk pilihan empat option jawaban. Sebelum 
penelitian dilakukan, instrumen penelitian terlebih dahulu diuji validitas dan reliabilitasnya.

1. Validitas

Pengujian validitas dalam penelitian ini dioperasikan dengan menggunakan program SPSS versi 16.0 dengan model Alpha Cronbach maka kriteria validnya instrumen adalah jika rhitung $>$ rtabel dengan alpha sebesar 0,05 maka instrumen dinyatakan valid. Hasil yang diperoleh dari pengujian ini disajikan pada table berikut:

\section{Tabel 1.}

Validitas Angket Peduli Sosial

\begin{tabular}{|c|c|c|c|}
\hline No & r Hitung & r Tabel $5 \%$ & Keterangan \\
\hline 1 & 0,794 & 0,374 & Valid \\
\hline 2 & 0,619 & 0,374 & Valid \\
\hline 3 & 0,794 & 0,374 & Valid \\
\hline 4 & 0,629 & 0,374 & Valid \\
\hline 5 & 0,737 & 0,374 & Valid \\
\hline 6 & 0,511 & 0,374 & Valid \\
\hline 7 & 0,549 & 0,374 & Valid \\
\hline 8 & 0,908 & 0,374 & Valid \\
\hline 9 & 0,542 & 0,374 & Valid \\
\hline 10 & 0,503 & 0,374 & Valid \\
\hline 11 & 0,575 & 0,374 & Valid \\
\hline 12 & 0,614 & 0,374 & Valid \\
\hline 13 & 0,828 & 0,374 & Valid \\
\hline 14 & 0,468 & 0,374 & Valid \\
\hline 15 & 0,816 & 0,374 & Valid \\
\hline 16 & 0,500 & 0,374 & Valid \\
\hline 17 & 0,701 & 0,374 & Valid \\
\hline 18 & 0,521 & 0,374 & Valid \\
\hline 19 & 0,718 & 0,374 & Valid \\
\hline 20 & 0,438 & 0,374 & Valid \\
\hline 21 & 0,705 & 0,374 & Valid \\
\hline 22 & 0,765 & 0,374 & Valid \\
\hline
\end{tabular}




\begin{tabular}{llll}
\hline 23 & 0,555 & 0,374 & Valid \\
24 & 0,778 & 0,374 & Valid \\
25 & 0,506 & 0,374 & Valid \\
26 & 0,839 & 0,374 & Valid \\
27 & 0,683 & 0,374 & Valid \\
28 & 0,622 & 0,374 & Valid \\
29 & 0,643 & 0,374 & Valid \\
30 & 0,494 & 0,374 & Valid \\
31 & 0,688 & 0,374 & Valid \\
32 & 0,638 & 0,374 & Valid \\
33 & 0,591 & 0,374 & Valid \\
34 & 0,614 & 0,374 & Valid \\
35 & 0,789 & 0,374 & Valid \\
\hline
\end{tabular}

$\mathrm{N}=30$ responden

Hasil uji validitas dengan menggunakan sampel 30 dan jumlah soal keterampilan sosial sebanyak 35 item dinyatakan valid dengan taraf signifikan 0,05 , kerena $\mathrm{r}$ hitung $>\mathrm{r}$ tabel. Maka instrumen tersebut valid dan layak digunakan sebagai instrument penelitian.

\section{Reliabilitas}

Uji reliabelitas dilakukan dengan melihat hasil dari Cronbach's Alpha Coefficient. Suatu instrument dikatan reliable bila memiliki koefisien keandalan reliabilitas sebesar 0,6 atau lebih. Hasil pengujian reliabilitas dapat dilihat pada tabel berikut:

Tabel 2.

Reliabelitas Angket Peduli Sosial

\begin{tabular}{cccc}
\hline No & $\begin{array}{c}\text { Cronbach's Alpha if } \\
\text { Item Deleted }\end{array}$ & $\begin{array}{c}\text { Cronbach's } \\
\text { Alpha }\end{array}$ & Keterangan \\
\hline 1 & 0,964 & 0,600 & Reliabel \\
2 & 0,965 & 0,600 & Reliabel \\
3 & 0,964 & 0,600 & Reliabel \\
4 & 0,965 & 0,600 & Reliabel \\
\hline
\end{tabular}




\begin{tabular}{|c|c|c|c|}
\hline 5 & 0,965 & 0,600 & Reliabel \\
\hline 6 & 0,966 & 0,600 & Reliabel \\
\hline 7 & 0,966 & 0,600 & Reliabel \\
\hline 8 & 0,964 & 0,600 & Reliabel \\
\hline 9 & 0,966 & 0,600 & Reliabel \\
\hline 10 & 0,966 & 0,600 & Reliabel \\
\hline 11 & 0,966 & 0,600 & Reliabel \\
\hline 12 & 0,965 & 0,600 & Reliabel \\
\hline 13 & 0,964 & 0,600 & Reliabel \\
\hline 14 & 0,966 & 0,600 & Reliabel \\
\hline 15 & 0,964 & 0,600 & Reliabel \\
\hline 16 & 0,966 & 0,600 & Reliabel \\
\hline 17 & 0,965 & 0,600 & Reliabel \\
\hline 18 & 0,966 & 0,600 & Reliabel \\
\hline 19 & 0,965 & 0,600 & Reliabel \\
\hline 20 & 0,966 & 0,600 & Reliabel \\
\hline 21 & 0,965 & 0,600 & Reliabel \\
\hline 22 & 0,965 & 0,600 & Reliabel \\
\hline 23 & 0,966 & 0,600 & Reliabel \\
\hline 24 & 0,965 & 0,600 & Reliabel \\
\hline 25 & 0,966 & 0,600 & Reliabel \\
\hline 26 & 0,964 & 0,600 & Reliabel \\
\hline 27 & 0,965 & 0,600 & Reliabel \\
\hline 28 & 0,965 & 0,600 & Reliabel \\
\hline 29 & 0,965 & 0,600 & Reliabel \\
\hline 30 & 0,966 & 0,600 & Reliabel \\
\hline 31 & 0,965 & 0,600 & Reliabel \\
\hline 32 & 0,965 & 0,600 & Reliabel \\
\hline 33 & 0,965 & 0,600 & Reliabel \\
\hline 34 & 0,965 & 0,600 & Reliabel \\
\hline 35 & 0,965 & 0,600 & Reliabel \\
\hline
\end{tabular}


Berdasarkan tabel hasil uji reliabelitas data, menunjukan bahwa setiap item memiliki koefisien alpha lebih besar dari 0,6. Hal ini berarti setiap item pertanyaan tersebut telah reliabel. Dapat dilihat pada tabel data yang telah diolah dengan bantuan SPSS 17 For windows Cronbanch's Alpha. Bahwa masing-masing pertanyaan menunjukan nilai reliable rata-rata di atas 0,900 , itu berarti bahwa tingkat reliable data terhitung tinggi kerena telah mendekati angka satu.

Setelah dilakukan uji validitas dan reliabilitas maka selanjutnya dilakukan uji normalitas dan uji homogenitas dimana untuk menguji normalitas instrumen dilakukan statistic Kolmogorov smirnov sedangkan uji homogenitas menggunakan uji lavene. Pengelolaan data dilakukan melalui beberapa tahapan, yaitu editing, skoring, konding, tabulating. Setelah data terkumpul baru dilakukan analisis data. Analisa data yang digunakan adalah rumus prosentase dan uji regresi linear sederhana.

Adapun Teknik analisa data yang dipergunakan dalam penelitian ini adalah diarahkan untuk menjawab rumusan atau menguji hipotesis yang telah dirumuskan. Maka tehnik analisis data yang dipergunakan adalah metode statistik yang telah tersedia yaitu dengan cara mengola data yang bersifat kuantitatif berwujud angka-angka dengan menggunakan bantuan computer pada program Statistical Package for the Sosial Sciences (SPSS) Adapun tehnik analisa statistiknya sebagai berikut:

Untuk menjawab rumusan masalah 1 dan 2 maka peneliti menggunakan analisis distribusi frekuensi relatif dengan prosentase sebagai berikut:

$$
P=\frac{F \times 100}{n}
$$

Keterangan :

f : Frekuensi yang sedang di cari prosentasenya

$\mathrm{N}$ : Number of cases (jumlah frekuensi/banyaknya lndividu)

$\mathrm{P}$ : Angka prosentase

Sedangkan untuk pengujian hipotesis menggunakan regresi linier sederhana dengan rumusan sebagai berikut :

$$
\operatorname{rxy}=\frac{\sum x y}{\sqrt{\left(\sum x^{2}\right)}\left(\sum y^{2}\right)} \longrightarrow \mathrm{y}=\mathrm{K}+\mathrm{ax}
$$

Keterangan :

rxy $=$ Koefisien korelasi antara dua variable $\mathrm{x}$ dan $\mathrm{y}$

$\sum x y=$ Jumlah hasil perkalian antara skor $\mathrm{x}$ dan $\mathrm{y}$ 


$$
\begin{aligned}
& \sum x=\text { Jumlah seluruh skor } \mathrm{x} \\
& \sum y=\text { Jumlah seluruh skor } \mathrm{y}
\end{aligned}
$$

Sebelum melakukan analisis hipotesis, peneliti melakukan uji normalitas dan homogenitas untuk mengetahui apakah data berdistribusi normal dan homogen.

\section{HASIL DAN PEMBAHASAN}

Untuk mengetahui ada tidaknya Pengaruh Pembelajaran Pendidikan IPS MI/SD terhadap Pembentukan Karakter Peduli Sosial Mahasiswa PGMI UNISKA MAB Banjarmasin, maka dalam Bab V ini penulis akan membahas tentang hasil analisa data, pengujian hipotesis dan pembahasan hasil supaya data yang diperoleh sesuai dengan apa yang diharapkan, maka instrument penelitiannya adalah dengan memecah variabel dan indikatornya, kemudian menjadi item-item pertanyaan atau pernyataan (data kuantitatif).

Sebagaimana sudah dijelaskan di atas, bahwa proses pengumpulan data untuk Pembelajaran Pendidikan IPS MI/SD dan Pembentukan Karakter Peduli Sosial Mahasiswa PGMI UNISKA MAB Banjarmasin menggunakan penyebaran angket sejumlah 51 responden pada mahasiswa PGMI UNISKA MAB Banjarmasin. Setelah data terkumpul, maka penulis berusaha untuk menganalisis sehingga data tersebut dapat membuktikan hipotesis yang telah direncanakan.

1. Pembelajaran Pendidikan IPS MI/SD

Berkaitan dengan Pembelajaran Pendidikan IPS MI/SD dapat dilihat sebagaimana tabel berikut:

\section{Tabel 3.}

Pembelajaran Pendidikan IPS MI/SD

\begin{tabular}{|c|c|c|c|}
\hline Interval & Frequensi & Prosentase & Kategori \\
\hline $120-126$ & 21 & $41,1 \%$ & Sangat Rendah \\
\hline $127-133$ & 18 & $35,2 \%$ & Rendah \\
\hline $134-140$ & 9 & $17,6 \%$ & Sedang \\
\hline $141-147$ & 2 & $3,9 \%$ & Tinggi \\
\hline $148-154$ & 1 & $1,9 \%$ & Sangat Tinggi \\
\hline
\end{tabular}


Berdasarkan table di atas dapat dikemukakan bahwa dari 51 mahasiswa menunjukkan kategori sangat tinggi dengan frekwensi 1 prosentase 1,9\%, Katagori tinggi dengan frequensi 2 prosentase 3,9 \%, Katagori sedang dengan frequensi 9 prosentase 17,6 \% dan kategori rendah dengan frekwensi 18 prosentase 35,2 \%, sedangkan kategori sangat rendah dengan frekwensi 21 prosentase 41,1\%.

2. Pembentukan Karakter Peduli Sosial Mahasiswa

Berkaitan dengan Karakter Peduli Sosial Mahasiswa dapat dilihat sebagaimana tabel berikut:

\section{Tabel 4.}

Pembentukan Karakter Peduli Sosial Mahasiswa

\begin{tabular}{cccc}
\hline Interval & Frequensi & Prosentase & Kategori \\
\hline $110-115$ & 8 & $15,6 \%$ & Sangat Rendah \\
$116-121$ & 6 & $11,7 \%$ & Rendah \\
$122-127$ & 16 & $31,3 \%$ & Sedang \\
$128-133$ & 16 & $31,3 \%$ & Tinggi \\
$134-139$ & 5 & $9,8 \%$ & Sangat Tinggi \\
\hline
\end{tabular}

Berdasarkan prosentase dari pengklasifikasian dan pengkategorian pada tabel di atas disimpulkan bahwa Karakter Peduli Sosial Mahasiswa adalah sebagai berikut: 15,6\% berkategori sangat rendah, $11.7 \%$ berkategori rendah, 31,3\% sedang, 31,3\% tinggi dan 9,8\% berkategori sangat tinggi. Sebelum dilakukan uji hipotesis, terlebih dahulu dilakukan uji normalitas dan uji homogenitas varians sebagai prasyarat untuk pengujian hipotesis.

\section{Normalitas}

Uji normalitas dimaksudkan untuk mengetahui apakah data yang diperoleh berdistribusi normal atau tidak. Uji normalitas dilakukan dengan menggunakan uji Kolmogorov Smirnov (K-S) dengan bantuan program SPSS versi 17.

\section{One-Sample Kolmogorov-Smirnov Test}

\begin{tabular}{|c|c|c|}
\hline & & $\begin{array}{l}\text { Unstandardize } \\
\text { d Residual }\end{array}$ \\
\hline \multicolumn{2}{|c|}{$\mathrm{N}$} & 51 \\
\hline Normal Parameters ${ }^{\mathrm{a}, \mathrm{b}}$ & Mean & .0000000 \\
\hline
\end{tabular}




\begin{tabular}{|c|c|c|}
\hline \multirow{4}{*}{$\begin{array}{c}\text { Most Extreme } \\
\text { Differences }\end{array}$} & Std. Deviation & 4.49308627 \\
\hline & Absolute & .176 \\
\hline & Positive & .134 \\
\hline & Negative & -.176 \\
\hline Kolmoge & irnov Z & 1.256 \\
\hline Asymp & tailed) & .085 \\
\hline
\end{tabular}

a. Test distribution is Normal.

b. Calculated from data.

Hasil pengujian menunjukkan semua nilai signifikansi uji normalitas dengan metode kolgomorov smirnov diperoleh lebih besar dari 0,05. Pada tabel di atas dapat dilihat bahwa untuk untuk pembelajaran pendidikan IPS menunjukkan angka 0,085 dan untuk karakter peduli sosial diperoleh angka 0,085, hasil probabilitas tersebut menunjukan semua data keterampilan sosial telah berdistribusi normal. Karena data berdistribusi normal, maka analisis dapat diteruskan menggunakan analisis parametrik dengan regresi linier sederhana.

\section{Homogenitas}

Pengujian homogenitas antar sampel dilakukan dengan levene's Test for Equality of $V$ ariances. Apabila nilai probabilitas lebih besar dari taraf signifikansi maka varian antar kelompok adalah homogeny. Sebaliknya jika probabilitas yang dihasilkan lebih kecil dari taraf signifikansi, maka varian antar kelompok heterogen. Hasil pengujian homogenitas dapat dilihat pada hasil SPSS tabel berikut:

\section{Test of Homogeneity of Variances}

Pembelajaran

\begin{tabular}{|r|r|r|r|}
\hline $\begin{array}{l}\text { Levene } \\
\text { Statistic }\end{array}$ & df1 & df2 & \multicolumn{1}{c|}{ Sig. } \\
\hline 1.726 & 14 & 28 & .107 \\
\hline
\end{tabular}

Berdasarkan hasil perhitungan melalui SPSS di atas diperoleh nilai signifikansi sebesar 0,107, perolehan tersebut lebih besar dari pada 0,05, hal tersebut menunjukan bahwa varian kedua sampel adalah homogeny.

5. Uji Hipotesis 
Uji hipotesis dilakukan untuk menjawab rumusan masalah nomor 2, maka uji hipotesis yang digunakan adalah dengan menggunakan regresi linier sederhana. regresi linier sederhana ini dilakukan untuk mengetahui pengaruh pembelajaran pendidikan IPS terhadap pembentukan karakter peduli sosial mahasiswa. Pengolahan data dilakukan dengan menggunakan statistik SPSS, dengan ketentuanya sebagai berikut:

Hipotesis:

Ho $=$ Tidak terdapat pengaruh pembelajaran pendidikan IPS terhadap pembentukan karakter peduli sosial mahasiswa.

$\mathrm{H1}=$ Terdapat pengaruh pembelajaran pendidikan IPS terhadap pembentukan karakter peduli sosial mahasiswa.

Adapun yang menjadi dasar pengambilan keputusan dalam analisis regresi sederhana ini dengan melihat nilai signifikansi.

a. Jika nilai signifikansi (Sig.) lebih besar $>$ dari propabilitas 0,05, maka tidak ada pengaruh pembelajaran pendidikan IPS terhadap pembentukan karakter peduli sosial mahasiswa.

b. Jika nilai signifikansi (Sig.) lebih kecil < dari propabilitas 0,05, maka ada pengaruh pembelajaran pendidikan IPS terhadap pembentukan karakter peduli sosial mahasiswa.

Hasil output pengolahan SPSS diperoleh

Coefficients $^{a}$

\begin{tabular}{|c|c|c|c|c|c|c|}
\hline & \multirow[b]{2}{*}{ Model } & \multicolumn{2}{|c|}{$\begin{array}{c}\text { Unstandardized } \\
\text { Coefficients }\end{array}$} & \multirow{2}{*}{$\begin{array}{c}\begin{array}{c}\text { Standardized } \\
\text { Coefficients }\end{array} \\
\text { Beta }\end{array}$} & \multirow[b]{2}{*}{$\mathrm{t}$} & \multirow[b]{2}{*}{ Sig. } \\
\hline & & $\mathrm{B}$ & Std. Error & & & \\
\hline \multirow[t]{2}{*}{1} & (Constant) & 12.703 & 11.511 & & 1.104 & .275 \\
\hline & Peduli_sosial & .909 & .091 & .819 & 9.984 & .000 \\
\hline
\end{tabular}

a. Dependent Variable: Pembelajaran

Diketahui dari hasil spss di atas nilai signifikansi (sig) sebesar 0,000 lebih kecil dari probabilitas (sig.) 0,05, Kerena probabilitas (sig.) 0,000 < 0,05 maka Ho ditolak, dan H1 diterima yang artinya terdapat pengaruh pembelajaran pendidikan IPS terhadap pembentukan karakter peduli sosial mahasiswa. Maka dari pada itu dapat disimpulkan Berdasarkan pengolahan data tersebut, maka dapat disimpulkan bahwa terdapat pengaruh pembelajaran pendidikan IPS terhadap pembentukan karakter peduli sosial mahasiswa. Pengaruh pembelajaran pendidikan IPS tersebut juga terlihat ungkapan dari beberapa orang sampel, mereka mengungkapkan setelah pembelajaran 
IPS lebih sering memperhatikan keadaan sosial di sekitar lingkunganya mereka, dan sudah ada terlintas di hati mereka ketika menemui orang yang memiliki masalah. Hal tersebut termasuk sejalan dengan yang diungkapkan Sam'ani, dkk. tentang nilai inti kepedulian sosial dalam pendidikan karakter di Indonesia dapat diturunkan menjadi nilai-nilai turunan yaitu: kasih sayang, perhatian, kebijakan, adab, komitmen, keharuan, kegotong royongan, santun, rasa hormat, demokratis, kebijaksanaan, disiplin, empati, kesetaraan, suka pemaaf, persahabatan, kesahajaan, kedermawanan, kelemah lembutan, pandai berterima kasih, pandai bersyukur, suka membantu, suka menghormati, keramah tamahan, kemanusiaan, kerendah hatian, kesetiaan, moderasi, kelembutan hati, kepatuhan, kebersamaan, toleransi dan punya rasa humor. (Samani \& Hariyanto, 2014).

Disamping itu Ischak, dalam (Sari, 2014) juga menjelaskan tujuan pendidikan IPS di SD adalah sebagai berikut: 1) Membekali anak didik dengan pengetahuan sosial yang berguna dalam kehidupan kelak di masyarakat. 2) Membekali anak didik dengan kemampuan mengidentifikasi, menganalisis dan menyusun alternatif pemecahan masalah sosial yang terjadi dalam kehidupan masyarakat. 3) Membekali anak didik dengan kemampuan berkomunikasi dengan sesama warga masyarakat dan berbagai bidang keilmuan serta bidang keahlian. 4) Membekali anak didik dengan kesadaran, sikap mental yang positif dan keterampilan terhadap pemanfaatan lingkungan hidup yang menjadi bagian dari kehidupan tersebut. 5) Membekali anak didik dengan kemampuan mengembangkan pengetahuan dan keilmuan IPS sesuai dengan perkembangan kehidupan masyarakat, ilmu pengetahuan dan teknologi.

Untuk mengetahui besarnya pengaruh pembelajaran pendidikan IPS terhadap pembentukan karakter peduli sosial mahasiswa dapat dilihat dari koefisien determinasi (R-Square).

\section{Model Summary}

\begin{tabular}{|c|r|r|r|r|}
\hline Model & \multicolumn{1}{|c|}{$\mathrm{R}$} & R Square & \multicolumn{1}{c|}{$\begin{array}{c}\text { Adjusted R } \\
\text { Square }\end{array}$} & $\begin{array}{c}\text { Std. Error of } \\
\text { the Estimate }\end{array}$ \\
\hline 1 & $.819^{\mathrm{a}}$ & .670 & .664 & 4.539 \\
\hline
\end{tabular}

a. Predictors: (Constant), Peduli_sosial

Dari hasil spss di atas diketahui bahwa hasil R-Square $=0,670$. Dengan demikian besarnya pengaruh pembelajaran pendidikan IPS terhadap pembentukan karakter peduli sosial mahasiswa adalah sebesar $67 \%$, sedangkan sisanya $33 \%$ dipengaruhi oleh faktor lain di luar penelitian ini. Abdul Majid dan Dian Andayani Strategi pendidikan karakter dalam satuan pendidikan dikelompokkan menjadi empat pilar yaitu: kegiatan belajar mengajar di kelas, kegiatan keseharian dalam bentuk budaya 
satuan pendidikan dan kegiatan ekstrakulikuler dan kegiatan keseharian di rumah. (Majid \& Andayani, 2013). Menurut Dirjen Dikdasmen Kemendiknas Pendidikan karakter dapat diintegrasikan dalam pembelajaran. Materi pembelajaran yang berkaitan dengan norma dan nilai perlu dikembangkan, dieksplisitkan, dikaitkan dengan konteks kehidupan. Dengan demikian pembelajaran nilai karakter tidak hanya pada ranah kognitif, nemun menyentuh pada internalisasi dan pengalaman nyata. (Kemendiknas, 2010)

\section{SIMPULAN}

Berdasarkan dari hasil penelitian yang penulis lakukan tentang pengaruh pembelajaran pendidikan IPS terhadap pembentukan karakter peduli sosial mahasiswa, dapat penulis simpulkan sebagai berikut:

1. Dari Pembelajaran pendidikan IPS MI diperoleh 21 mahasiswa (41,1\%) berkategori sangat rendah, 18 mahasiswa (35.2\%) berkategori rendah, 9 mahasiswa $(17,6 \%)$ sedang, 2 mahasiswa (3,9\%) tinggi dan 1 mahasiswa $(1,9 \%)$ berkategori sangat tinggi. Sedangkan karakter peduli sosial 8 mahasiswa $(15,6 \%)$ berkategori sangat rendah, 6 mahasiswa (11.7\%) berkategori rendah, 16 mahasiswa $(31,3 \%)$ sedang, 16 mahasiswa (31,3\%) tinggi dan 5 mahasiswa (9,8\%) berkategori sangat tinggi.

2. Dari hasil statistik regresi linier sederhana diketahui nilai signifikansi (sig) sebesar 0,000 lebih kecil dari probabilitas (sig.) 0,05, Kerena probabilitas (sig.) 0,000<0,05 maka dapat disimpulkan bahwa terdapat pengaruh pembelajaran pendidikan IPS terhadap pembentukan karakter peduli sosial mahasiswa. Besarnya pengaruh pembelajaran pendidikan IPS terhadap pembentukan karakter peduli sosial mahasiswa adalah sebesar $67 \%$, sedangkan sisanya $33 \%$ dipengaruhi oleh faktor lain.

\section{DAFTAR PUSTAKA}

Apriyanti, P. (2014). Hubungan Kompetensi Pedagogik Guru Dengan Hasil Belajar Siswa Pada Mata Pelajaran Ilmu Pengetahuan Sosial (IPS) Di SD Negeri 60 Kota Bengkulu. Bengkulu: Skripsi Universitas Bengkulu

Arikunto, S. (2006). Prosedur Penelitian suatu Pendekatan Praktek. Jakarta : Rineka Cipta.

Asmani, J. M. (2011). Buku Panduan Internalisasi Pendidikan Karakter di Sekolah, cet. ke-2. Jogyakarta: Diva Press.

Budiningsih, A. (2004). Pembelajaran Moral. Jakarta: Rineka Cipta. 
Elly, M. S., \& dkk. (2012). Ilmu Sosial dan Budaya dasar. Jakarta: Kencana

Hidayatullah, F. (2010). Pendidikan Karakter: Membangun Peradaban Bangsa. Surakarta: Yuma Pustaka.

Kemendiknas, D. D. (2010). Pembinaan Pendidikan Karakter di Sekolah Menengah Pertama. Jakarta: Dirjen Dikdasmen Kemendiknas.

Listyarti, R. (2012). Pendidikan Karakter dalam Metode Aktif, Inovatif dan Kreatif, Esensi. Jakarta.

Majid, A., \& Andayani, D. (2013). Pendidikan Karakter Perspektif Islam. Bandung: Remaja Rosdakarya.

Mustari, M. (2014). Nilai Karakter Refleksi Untuk Pendidikan,. Jakarta: Raja Grafindo Persada.

Narwati, S. (2011). Pendidikan Karakter. Yogyakarta: Familia.

Samani, M., \& Hariyanto. (2014). Konsep dan Model Pendidikan Karakter. Bandung : Rosda Karya.

Saputra, T. A. (2009). Pembelajaran IPS Di Sekolah Dasar Berbasis Pembelajaran Tematik. Edubumaniora, Vol. 1, No. 2

Sari, R. A. (2014). Hubungan Minat Belajar Siswa Dengan Hasil Belajar IPS Di SD Gugus 1 Kabupaten Kepabiang. Bengkulu: Skripsi. Universitas Bengkulu

Somad, A. (2006). Pendidikan Nilai Sebagai Basic Pembinaan Nilai Generasi Muda. Buletin Gerakan Indonesia Bersatu.

Sugiono. (2005). Metode Penelitian Kuantitatif, Kuantitatif dan R \&D. Bandung: Alfabeta

Warsono. (2006). Membangun Moral Generasi Muda melalui Gerakan Pramuka. Surabaya: disampaikan dalam Musda Pramuka Provinsi Jatim.

Yaumi, M. (2004). Pendidikan Karakter : Landasan, Pilar dan Implementasi. Jakarta: Kencana.

Zuchdi, D. (2007). Pendidikan Karakter dalam Perspektif Teori dan Praktek. Yogyakarta: UNY Press. 